\title{
AKTIVITAS LARUTAN TANAMAN SIRIH HUTAN (Piper aduncum L.) SEBAGAI PEMICU PERTUMBUHAN JAMUR MERANG (Volvariella volvaceae L)
}

\section{FITRIYA CANDRA DEWI ${ }^{1}$. AUNG SUMBONO ${ }^{1.2}$. ANDI FIRMANSYAH ${ }^{1}$. ENDANG GUNAISAH $^{3}$}

1. Program Studi Pendidikan Biologi Universitas Pendidikan Muhammadiyah Sorong

${ }^{2 .}$ Laboratorium Kimia MAN Model Kota Sorong

3. Akademi Perikanan Sorong

fitriyacandradewi@gmail.com

\begin{abstract}
ABSTRAK
Tujuan penelitian yakni untuk mengetahui aktivitas larutan tanaman sirih hutan (Piper aduncum L.) sebagai pemicu pertumbuhan jamur merang (Volvariella volvaceae). Penelitian ini merupakan eksperimen. Sampel adalah jerami tangkai buah padi, larutan hasil destilasi dari akar, batang, daun. Instrumen pengambilan data yakni dokumentasi, observasi, lup. Tempat penelitian di Laboratorium MAN Model Sorong dan Laboratorium MIPA UNIMUDA Sorong serta Laboratorium Pengamatan Hama Penyakit (LPHP) Sorong. Uji prasyarat menggunakan uji normalitas. Uji hipotesis menggunakan uji mann-whitney. Analisa data dilakukan dengan menggunakan statistik SPSS 16. Hasil penelitian diperoleh bahwa konsentrasi larutan akar terbaik yakni pada konsentrasi 25\% a symp sig 2 tailed $0,280>$ dari 0,05 pada hari ke 2 . Konsentrasi larutan dari batang terbaik yakni 20\% a symp sig 2 tailed 0,353 > dari 0,05 pada hari ke 5. Konsentrasi larutan dari daun terbaik yakni 30\% a symp sig 2 tailed $0,353>$ dari 0,05 pada hari ke 5. Larutan akar, batang dan daun secara keseluruhan dapat memicu pertumbuhan jamur Volvarialla volvaceae $L$ dan yang terbaik adalah larutan dari daun dengan konsentrasi terbaik yakni $30 \%$ a symp sig 2 tailed $0,353>$ dari 0,05 pada hari ke 5 .

Kata kunci: Sirih, jamur, Piper aduncum L., Volvariella volvaceae $L$
\end{abstract}

\section{ABSTRACH}

The purpose of the research is to know the activity of the forest plant betel (Piper aduncum L.) as the trigger for the growth of mushroom (Volvariella volvaceae). This research is an experiment. Samples are rice stalk straw, sample of distillation solution from roots, stems, leaves. Instrument of data collection that is documentation, observation, loop. Place of research in Laboratory of MAN Model Sorong and Laboratory of MIPA UNIMUDA Sorong and Laboratorium Pengamatan Hama Penyakit (LPHP) Sorong. The prerequisite test uses the normality test. Hypothesis test using mann-whitney test. Data analysis was performed using SPSS 16 statistic. The result showed that the best root concentration concentration was at concentration 25\% a symp sig 2 tailed 0,280> from 0,05 at day 2. The concentration of the solution from the best stem is $20 \%$ a sq. 2 tailed symp. $0.353>$ from 0.05 on the 5 th day. The concentration of the best leaf solvent is $30 \%$ a symp sig 2 tailed $0.353>$ from 0.05 on day 5 . Root, stem and leaf solution as a whole can trigger the growth of Volvarialla volvaceae $L$ fungus and the best is the leaf solution with the best concentration of $30 \%$ a symp sig 2 tailed $0.353>$ from 0,05 on day 5.

Keywords: Betel, mushroom, Piper aduncum L., Volvariella volvaceae L

\section{PENDAHULUAN}

Jamur telah dianggap sebagai bahan masakan di seluruh dunia, terutama untuk keunikan rasa dan telah dihargai oleh manusia sebagai keajaiban kuliner. Lebih dari 2.000 spesies jamur ada di alam, tapi sekitar 25 diterima secara luas sebagai makanan dan beberapa secara komersial dibudidayakan 
(Valverde. ME, et al, 2015).

Jamur memainkan peran penting dalam kehidupan manusia karena berbagai manfaat. Praktek-praktek budidaya jamur dapat meningkatkan perekonomian negara dan dapat meningkatkan ketahanan pangan dengan pemanfaatan sumber daya alam (Semwal. KC, et al, 2014). Kerugian yang ditimbulkan oleh penyakit layu akibat jamur Verticillium tidak sedikit, terutama karena terjadinya penurunan hasil. Jumlah tanaman ubi kentang terinfeksi jamur Verticillium tidak berbeda nyata dengan tanaman sehat, tetapi bobot ubi kentang justru menurun bahkan sampai 50\% (Suganda, 1995). Sedangkan di Kolumbia, Amerika Selatan, dilaporkan kerugian hasil tanaman kentang mencapai 100\% (Malamud, 1989).

Jenis-jenis jamur yakni dari jamur yang ringan sampai yang beracun dan mematikan (Aziz. S.M.A, et al, 2015). Jika dikonsumsi secara sengaja, menyebabkan masalah kesehatan yang parah dan dapat menyebabkan kematian, jamur beracun yang mematikan yakni genus Amanita terutama Amanita muscaria (Fly Agaric), Amanita virosa (Destroying angel), dan phalloides Amanita (Death cap), mengandung endotoksin yaitu, Phallotoxins dan Amatoxins. Phallotoxins menyebabkan sakit perut, otot kram, gagal ginjal diikuti dengan kematian. Amantoxin juga memiliki efek yang sama dengan kegagalan tuas, kerusakan pada ginjal, iritasi di saluran pernapasan diikuti dengan sesak napas dan pusing. Beberapa spesies lainnya yaitu: Galerina autumnalis, Conocybe filaris juga memproduksi racun mematikan yang sama (Boa, 2004). Banyak jamur digunakan sebagai obat dalam masyarakat yang berbeda yakni digunakan untuk mencegah serangan jantung, kanker dan tumor (Chang, 1993). Jamur yang memiliki kandungan senyawa kimia yang bertanggung jawab untuk menyembuhkan infeksi virus, bakteri, penyakit jamur, menurunkan kolesterol darah dan lain lain. Jamur tersebut yakni Ganoderma (Lingzi) yang dikenal sebagai obat herbal ajaib pada obat tradisional Cina (TCM) yang tanpa efek samping, bahkan setelah mengkonsumsi untuk waktu yang lama. Jamur tersebut meningkatkan kemampuan penyembuhan tubuh, dan memberikan kehidupan yang panjang (anti penuaan dan vitalitas). Ganoderma lucidum (Reishi) memiliki molekul bioaktif yang berbeda yang memiliki aktivitas anti-kanker, anti-HIV, serangan anti-hati (penurun kolesterol), hipoglikemik (anti-diabetes) dan anti-oksidan (Willard, 2006). Secara umum pertumbuhan jamur dipengaruhi oleh substrat, kadar air, derajat keasaman substrat $(\mathrm{pH})$ dan senyawa kimia di lingkungannya.

Jamur pada pertumbuhannya memerlukan sumber mineral dolomit mengandung unsur $\mathrm{Ca}$ dan $\mathrm{Mg}$ (Pramita. I, et $a l, 2015) . \mathrm{Mg}$ berperan dalam sintesis protein, mendorong aktivitas enzim (Wibowo, 1983), dan memperbaiki kualitas nutrisi yang pada akhirnya menghasilkan pertumbuhan optimal pada jamur (Winarno, 2004). Pembentukan dan perkembangan tubuh buah dipengaruhi oleh banyak faktor, salah satunya yaitu faktor lingkungan. Faktor lingkungan umumnya akan berpengaruh pada pembentukan tubuh buah, diantaranya suhu media tanam, udara dan faktor cahaya (intensitas cahaya, komposisi dan waktu pencahayaan). Penambahan kapur merupakan hal yang berpengaruh terhadap tubuh buah jamur selain dari faktor lingkungan (Sumarsih, 2010), dengan pemberian thiamin ternyata mampu merangsang pertumbuhan akar pada tanaman (Wetherell, 2002). Pemberian jenis hormon berpengaruh secara signifikan terhadap panjang akar, diameter stek, dan tinggi tunas stek pada tanaman. Hormon yang paling baik dalam merangsang pertambahan jumlah akar (Jinus, et al, 2012). Faktor-faktor yang berpengaruh terhadap pertumbuhan dan perkembangan jamur antara lain nutrisi meliputi gula, polysakarida, asam-asam organik, lipid sebagai sumber karbon; nitrat, amonia, asam-asam amino, polipeptida dan protein sebagai sumber nitrogen; hidrogen, oksigen, sulfur, fosfor, magnesium, potasium (Carlile. M.J dan Watkinson. S.C, 1995).

Pertumbuhan jamur pada pangkal stek dapat disebabkaan oleh kondisi media yang terlalu lembab akibat penyiraman yang dilakukan setiap hari. Akibatnya adalah terjadi 
penggenangan air pada bagian pangkal stek yang menyebabkan pembusukan. Kebanyakan jamur yang menyerang stek tanaman sadalah jenis Fusarium oxysporum (Gardner, et al, 2002). Secara umum dalam budidaya jamur baik skala kecil maupun dalam skala besar, para petani menggunakan media umum yaitu serbuk kayu gergaji sebagai media tanam, akan tetapi sebagai konsekuensi yang akan timbul masalah apabila serbuk gergaji sulit diperoleh atau tidak ada sama sekali di lokasi yang akan menjadi sasaran penyebaran budidaya. Oleh karena itu, untuk mengantisipasi perlu dicari substrat alternatif yang banyak tersedia dan mudah diperoleh di daerah tersebut. Salah satu substrat yang dapat dijadikan alternatif dalam budidaya jamur adalah jerami (Wahidah. B.F, et al, 2015). Pemanfaatan blotong sebagai bahan campuran pembudidayaan jamur dikarenakan dapat meningkatkan hasil penen jamur karena bahan tersebut mengandung unsur hara esessial yaitu pentosan. Hasil penelitian penggunaan blotong ternyata dapat meningkatkan hasil jamur dibandingkan menggunakan pupuk NPK, dan TSP, sehingga blotong dapat digunakan sebagai pengaganti pupuk NPK dan TSP (Martina, 2004).

Berdasarkan hasil praktikum mahasiswa program studi Pendidikan Biologi, STKIP Muhammadiyah Sorong pada Praktikum Mata Kuliah Biokimia Pangan terbukti cairan sirih merah (Piper crocatum Rutz \& Pav) dapat memicu pertumbuhan jamur di media roti. Sirih merah (Piper crocatum Rutz \& Pav) merupakan famili tumbuhan sirih-sirihan. Tumbuhan yang merupakan family sirih dan endemik pulau Papua dan Maluku adalah sirih hutan (Piper aduncum L.).

Sirih hutan (Piper aduncum L.) yang merupakan endemik pulau Papua belum banyak digunakan oleh masyarakat. Selain dari itu penelitian tentang sirih hutan juga belum banyak dilaporkan. Beberapa penelitian yang telah mengarah pada pemanfaatan tanaman sirih hutan yakni tentang pemanfatan buah sirih untuk dijadikan gula (Sasabone. A, et al, 2016), sirih hutan digunakan untuk anti insektisida nabati
(Prakash. A, Rao J, 1997), tetapi belum ada penelitian penggunaan sirih hutan sebagai pemicu pertumbuhan jamur. Maka perlu dilakukan penelitian untuk mengetahui sirih hutan dapat digunakan sebagai pemicu pertumbuhan jamur. Tujuan penelitian yakni untuk megetahui aktivitas larutan tanaman sirih hutan (Piper aduncum L.) sebagai pemicu pertumbuhan jamur merang (Volvariella volvaceae $L$ )

\section{METODE PENELITIAN}

Penelitian ini merupakan suatu penelitian eksperimen (Ningsih. H. U., et al, 2015) skema rancangan penelitian seperti pada Gambar 2-1. Sampel dalam penelitian ini adalah jerami tangkai buah padi kemudian sampel larutan hasil destilasi dari akar, batang, daun sirih hutan (Piper aduncum L.).

Bahan yang digunakan dalam penelitian ini yakni: akar, batang, daun dari sirih hutan (Piper aduncum L.) dan air. Bahan pembuatan media yang digunakan adalah jerami tangkai buah padi. Alat-alat yang digunakan yakni: Kit destilasi timbangan (analitik) gelas ukur $(100 \mathrm{ml})$ mortal dan mortil blender spatula beaker glass $(100 \mathrm{ml})$ penjepit kayu lup (kaca pembesar) bunsen burner ember pisau korek api kamera. Alat Media Pertumbuhan Jamur adalah gunting dan gelas plastik.

Instrumen pengambilan data yakni dokumentasi, observasi dan lup (kaca pembesar). Data perkembangan proses pertumbuhan jamur dipantau mulai hari pertama perlakuan dan seterusnya hingga selesai. Pengulangan pemantauan masing-masing setiap 24 jam. Batas maksimum pemantauan dihentikan setelah beberapa hari setelah jamur tersebut tumbuh. Data jumlah jamur yang diperoleh akan dilakukan pentabelan untuk mempermudah proses perhitungan. Perhitungan jamur ketika jamur tersebut dikatakan lengkap maksudnya terdapat tangkai dan tudung jamur.

Tempat penelitian ini dilakukan di Laboratorium Man Model Sorong dan di Laboratorium MIPA Terpadu UNIMUDA Sorong serta Laboratorium Pengamatan Hama Penyakit (LPHP) Sorong. Pembuatan Larutan Destilasi Akar, Batang, Daun, Sirih 
Hutan 1). Mempersiapkan alat destilasi air. 2). Mempersiapkan alat-alat pendukung lainnya, seperti yang tercantum di atas pada alat pembuatan larutan. 3). Mempersiapkan akar, batang, daun sirih hutan dan jerami tangkai buah padi. 4). Pembuatan larutan akar, batang, daun sirih hutan, yakni a). Memisahkan akar,daun, batang, dan ditimbang. b). Akar, batang, daun sirih dicuci sampai bersih dan ditiriskan, c). Kemudian daun sirih hutan dimasukan bersama dengan air $100 \mathrm{ml}$, batang sirih hutan dengan air $100 \mathrm{ml}$, akar sirih hutan dengan air $60 \mathrm{ml}$ dalam blender dan dihaluskan. d). Setelah halus, dipindahkan ke dalam beaker glass kemudian ditimbang. Sebelum ditimbang menggunakan timbangan analitik antara beaker glass dengan timbangan harus normal. e). Kemudian didestilasi. Pembuatan Media Merang: 1). Media yang digunakan yakni jerami tangkai buah padi. 2). Jerami dipotong kecil-kecil hingga halus. 3). Jerami yang sudah dipotong diletakkan ke dalam gelas plastik. Perlakuan Penelitian: 1). Siapkan media merang dan larutan destilasi akar, batang, daun sirih hutan. 2). Hasil destilasi dicampur kedalam gelas puding plastik. 3). Dengan konsentrasi masing-masing batang dan daun $20 \%, 30 \%$, $40 \%$, dan akar 25\%, 50\%, 75\% sebanyak 10 buah per akar, batang, daun. 5). Identifikasi perkembangan jamur per 24 jam setelah 10 hari perlakuan selama jamur tersebut masih hidup atau belum membusuk 6). Analisis dengan program SPSS. Teknik analisis data yaitu uji prasyarat dan uji hipotesis. Uji prasyarat menggunakan uji normalitas. Uji hipotesis menggunakan uji mann-whitney. Analisa data dilakukan dengan menggunakan statistik SPSS 16.

\section{PEMBAHASAN}

Data hasil pembuatan sampel larutan sirih hutan diperoleh seperti ditampilkan pata Tabel 3-1.

Tabel 3-1. Pembuatan Sampel Larutan Sirih Hutan

\begin{tabular}{|l|l|l|l|l|}
\hline Bagian & $\begin{array}{l}\text { Konse } \\
\text { ntrasi }\end{array}$ & $\begin{array}{l}\text { Bobot } \\
\text { bahan }\end{array}$ & $\begin{array}{l}\text { Air } \\
\text { mineral }\end{array}$ & $\begin{array}{l}\text { Hasil } \\
\text { destilasi }\end{array}$ \\
\hline \multirow{4}{*}{ LA } & $25 \%$ & $15 \mathrm{gr}$ & $60 \mathrm{ml}$ & $26 \mathrm{ml}$ \\
\cline { 2 - 5 } & $50 \%$ & $30 \mathrm{gr}$ & $60 \mathrm{ml}$ & $28 \mathrm{ml}$ \\
\cline { 2 - 5 } & $75 \%$ & $45 \mathrm{gr}$ & $60 \mathrm{ml}$ & $30 \mathrm{ml}$ \\
\hline \multirow{2}{*}{ LB } & $20 \%$ & $25 \mathrm{~g}$ & $100 \mathrm{ml}$ & $43 \mathrm{ml}$ \\
\cline { 2 - 5 } & $30 \%$ & $50 \mathrm{~g}$ & $100 \mathrm{ml}$ & $52,5 \mathrm{ml}$ \\
\hline
\end{tabular}

\begin{tabular}{|l|l|l|l|l|}
\hline & $40 \%$ & $75 \mathrm{~g}$ & $100 \mathrm{ml}$ & $82 \mathrm{ml}$ \\
\hline \multirow{4}{*}{$\mathrm{LD}$} & $20 \%$ & $25 \mathrm{~g}$ & $100 \mathrm{ml}$ & $27 \mathrm{ml}$ \\
\cline { 2 - 5 } & $30 \%$ & $50 \mathrm{~g}$ & $100 \mathrm{ml}$ & $30 \mathrm{ml}$ \\
\cline { 2 - 5 } & $40 \%$ & $75 \mathrm{~g}$ & $100 \mathrm{ml}$ & $48 \mathrm{ml}$ \\
\hline
\end{tabular}

Data pertumbuhan jamur pada sampel eksperimen yang menggunakan larutan dari akar (LA) (Gambar 3-1) menunjukkan bahwa sampel pada eksperimen lebih dahulu muncul pertumbuhan jamur dibanding dengan KL yakni selisih pertumbuhan antara eskperimen terhadap KL adalah 2 hari observasi. Pertumbuhan jamur pada konsentrasi $30 \%$ di hari ke 1 lebih tinggi dibandingkan dengan konsentrasi lainnya tetapi keadaan menjadi terbalik pada hari ke 2 . Hari ke 3 peningkatan terjadi pada LA 30\% dan LA 40\%. Sedangkan pada LA 20\% meningkat tetapi sedikit. Pada hari ke 4 sampel kontrol terdapat pertumbuhan jamur tetapi masih jauh dibanding dengan jumlah jamur pada sampel baik yang LA $20 \%, 30 \%$ dan $40 \%$.

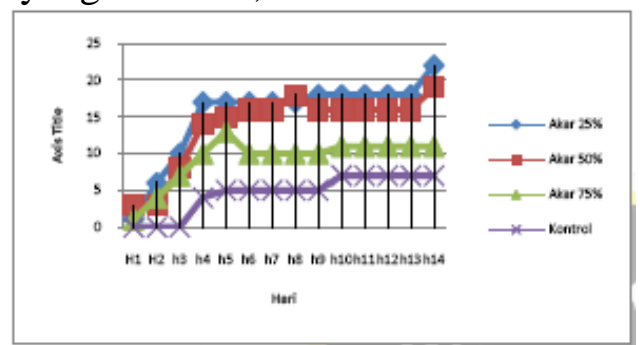

Gambar 3-1. Data hasil observasi pada sampel menggunakan LA.

Perbandingan sampel LA 20\%, 30\%, $40 \%$ selanjutnya pada konsentrasi $40 \%$ hingga ke hari 14 tetap lebih tinggi dibanding yang LA $20 \%$ dan LA 30\%. LA 30\% lebih tinggi pertumbuhan jamur dari LA 20\% kecuali hari ke 8 dimana konsentrasi $30 \%$ melampaui LA 40\%. Demikian pula perkembangan untuk kontrol terjadi peningkatan pada hari ke 4 dan hari ke 10 . Data pertumbuhan jamur pada sampel eksperimen yang menggunakan larutan dari batang (LB) (Gambar 3-2) menunjukkan bahwa sampel pada eksperimen lebih dahulu muncul pertumbuhan jamur dibanding dengan yang KL yakni selisih pertumbuhan antara eskperimen dan kontrol adalah 2 hari observasi. LB 40\% pada hari ke 1 lebih tinggi dibandingkan dengan konsentrasi lainnya tetapi keadaan menjadi terbalik pada hari ke 4 dimana LB 20\% lebih tinggi dibandingkan dengan LB $40 \%$ dan LB 30\%. Hari ke 2 
peningkatan terjadi pada LB $20 \%$ dan LB $30 \%$. Sedangkan yang LB $40 \%$ meningkat tetapi sedikit. Hari ke 6 peningkatan terjadi pada LB 20\% dibandingkan LB 30\% dan LB $40 \%$. Selanjutnya, perbandingan pada LB $40 \%$ hari ke 7 hingga hari ke 14 tetap lebih tinggi dibanding yang LB 20\% dan LB 30\%.

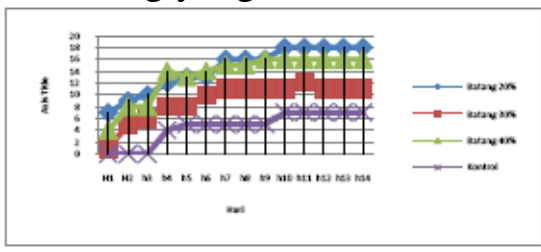

Gambar 3-2 Data hasil observasi pada sampel menggunakan larutan batang.

Data pertumbuhan jamur pada sampel menggunakan larutan dari daun (LD) (Gambar 3-3), menunjukkan bahwa sampel pada eksperimen lebih dahulu muncul pertumbuhan jamur dibanding dengan yang kontrol yakni selisih pertumbuhan antara eskperimen dan kontrol adalah 2 hari observasi. Sampel LD 30\% pada hari ke 1 lebih tinggi dibandingkan dengan konsentrasi lainnya. Hari ke 2 peningkatan terjadi pada LD $30 \%$ dan LD $20 \%$ sedangkan pada LD $40 \%$ meningkat tetapi sedikit. Hari ke 3 peningkatan terjadi pada LD 30\% sedangkan LD 20\% mengalami sedikit penurunan tetapi pada LD $40 \%$ tidak mengalami peningkatan. Hari ke 6 hingga hari ke 14 peningkatan terjadi pada konsentrasi 30\%. Selanjutnya, perbandingan pada LD 20\% hari ke 7 hingga hari ke 14 mengalami sedikit peningkatan sedangkan pada hari ke 9 hingga hari ke 14 mengalami sedikit peningkatan.

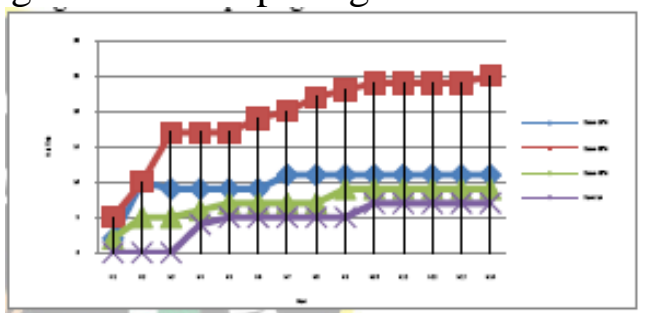

Gambar 3-3. Data hasil observasi pada sampel menggunakan LD.

Data pertumbuhan jamur pada sampel eksperimen yang menggunakan LA terhadap LD (Gambar 3-4), sampel LA terhadap LD diperoleh hasil yakni pertumbuhan jamur terbanyak pada LD 30\% dan yang paling sedikit yakni pada LD 40\%. Ini menunjukkan bahwa perbedaan konsentrasi larutan pada sampel dengan menggunakan daun lebih signifikan berbeda hasil pertumbuhan jamur dibanding dengan larutan yang berasal dari akar dengan bukti dimana grafik garis pertumbuhan jamur tidak signifikan berbeda antar konsentrasi.

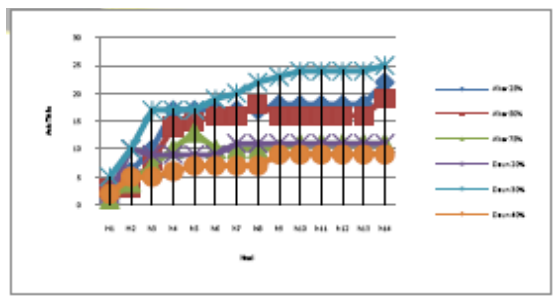

Gambar 3-4. Data perbandingan sampel menggunakan larutan akar dan daun.

Data pertumbuhan jamur pada sampel eksperimen yang menggunakan LB terhadap sampel eksperimen menggunakan larutan dari daun (Gambar 3-5) diperoleh hasil yakni pertumbuhan jamur terbanyak pada LB 30\% dan yang paling sedikit LB 40\%. Ini menunjukkan bahwa perbedaan konsentrasi larutan pada LD lebih signifikan berbeda hasil pertumbuhan jamur dibanding LB dengan bukti garis di grafik pertumbuhan jamur tidak signifikan berbeda antar konsentrasi.

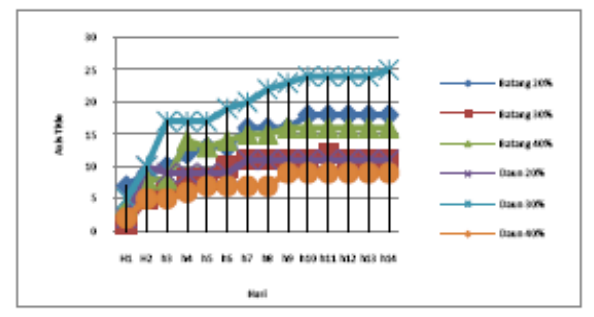

Gambar 3-5. Data perbandingan sampel menggunakan LB dan LD.

Data pertumbuhan jamur pada LA terhadap LB (Gambar 3-6) diperoleh hasil yakni pertumbuhan jamur terbanyak pada LA dengan konsentrasi $25 \%$ dan yang paling sedikit yakni LB kosentrasi 30\%. Ini menunjukkan bahwa perbedaan konsentrasi LA lebih signifikan berbeda hasil pertumbuhan jamur dibanding dengan LB. Berdasarkan perbandingan dapat dinyatakan secara garis besar adalah pertumbuhan jamur paling signifikan terjadi pada LD demikian pula perbandingan konsentrasi terjadi perbedaan yang sangat signifikan juga pada LD. 


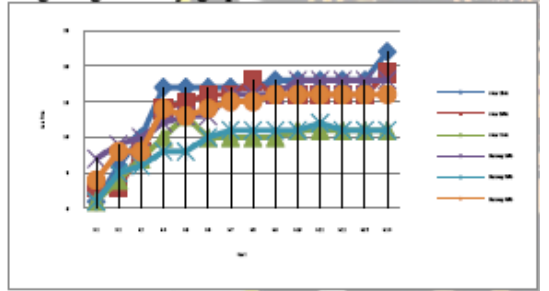

Gambar 3-6. Data perbandingan sampel menggunakan LB.

Sampel dilakukan penyemprotan 5 hari sekali untuk LA $25 \%, 50 \%, 75 \%$, LB $20 \%, 30 \%$, 40\%, dan LA 20\%, 30\%, $40 \%$ (Gambar G). pengamatan spora jamur per 24 jam setelah 10 hari perlakuan menggunakan Lup (Gambar H). Gambar I, J dan K merupakan tampilan hasil observasi spora jamur pada LB 25\%, 50\%, 75\%. Sedangkan Gambar L M dan $\mathrm{N}$ merupakan tampilan hasil observasi spora jamur pada LA $20 \%$, $30 \%, 40 \%$. Gambar O, P dan Q merupakan tampilan hasil observasi spora jamur pada LD $20 \%, 30 \%, 40 \%$. merupakan spora jamur pada LD 20\%. Sementara untuk Gambar R merupakan pengontrol berupa air dan terdapat spora jamur tetapi pertumbuhannya lambat tidak sebanyak yang menggunakan LA, LB dan LD.

Data hasil perhitungan LA $25 \%$ dapat ditarik suatu keputusan bahwa untuk data sampel pada hari ke 3 hingga hari ke 14 yang menggunakan LA $25 \%$ menunjukkan hipotesis awal (H0) diterima, sedangkan hipotesis alternative (H1) ditolak. Ini membuktikan bahwa untuk sampel pada hari ke 3 hingga hari ke 14 yang menggunakan LA $25 \%$ pertumbuhan jamur dibanding dengan KL tidak ada perbedaan atau dengan kata lain pemberian LA tidak berdampak terhadap pertumbuhan jamur. Sedangkan pada data yang ditampilkan pada tabel 4-2 hingga 4-3 dapat ditarik suatu keputusan bahwa untuk data sampel pada hari ke 1 hingga hari ke 2 dengan menggunakan LA 25\% menunjukkan hipotesis awal (H0) ditolak, sedangkan hipotesis alternative (H1) diterima. Ini membuktikan bahwa untuk sampel pada hari ke 1 hingga hari ke 2 dengan menggunakan LA $25 \%$ pertumbuhan jamur dibanding dengan kontrol ada perbedaan atau dengan kata lain pemberian LA berdampak terhadap pertumbuhan jamur. Data hasil perhitungan
LA 50\% dapat ditarik suatu keputusan bahwa data sampel pada hari ke 3-9 dengan menggunakan LA 50\% dan hari ke 14 dengan menggunakan LA $50 \%$ menunjukkan hipotesis awal (H0) diterima, sedangkan hipotesis alternative (H1) ditolak. Ini membuktikan bahwa untuk sampel pada hari ke 3-9 dengan menggunakan LA 50\% dan hari ke 14 dengan menggunakan LA 50\% pertumbuhan jamur dibanding dengan kontrol tidak ada perbedaan atau dengan kata lain pemberian larutan akar tidak berdampak terhadap pertumbuhan jamur. Sedangkan pada data LA $50 \%$ dapat ditarik suatu keputusan bahwa untuk data sampel pada hari ke 1 hingga hari ke 2 dengan menggunakan LA 50\% dan 10 hingga hari ke 13 dengan menggunakan LA $50 \%$ menunjukkan hipotesis awal (H0) ditolak, sedangkan hipotesis alternative (H1) diterima. Ini membuktikan bahwa untuk sampel pada hari ke 1 hingga hari ke 2 dengan menggunakan LA 50\% dan 10 hingga hari ke 13 dengan menggunakan LA $50 \%$ pertumbuhan jamur dibanding dengan kontrol ada perbedaan atau dengan kata lain pemberian larutan akar berdampak terhadap pertumbuhan jamur.

Data hasil perhitungan LA 75\% dapat ditarik suatu keputusan bahwa data sampel pada hari ke 3 hingga hari ke 5 dengan menggunakan LA $75 \%$ menunjukkan hipotesis awal (H0) diterima, sedangkan hipotesis alternative (H1) ditolak. Ini membuktikan bahwa untuk sampel pada hari ke 3 hingga hari ke 5 dengan menggunakan LA $75 \%$ pertumbuhan jamur dibanding dengan kontrol tidak ada perbedaan atau dengan kata lain pemberian larutan akar tidak berdampak terhadap pertumbuhan jamur. Sedangkan pada data juga dapat ditarik suatu keputusan bahwa untuk data sampel pada hari ke 1 hingga hari ke 2 pada hari ke 3 hingga hari ke 5 dengan menggunakan larutan LA $75 \%$ dan hari ke 6 hingga hari ke 14 pada hari ke 3 hingga hari ke 5 dengan menggunakan LA 75\% menunjukkan hipotesis awal (H0) ditolak, sedangkan hipotesis alternatif (H1) diterima. Ini membuktikan bahwa untuk sampel pada hari ke 1 hingga hari ke 2 pada hari ke 3 hingga hari ke 5 dengan 
menggunakan LA 75\% dan hari ke 6 hingga hari ke 14 pada hari ke 3 hingga hari ke 5 dengan menggunakan LA $75 \%$ pertumbuhan jamur dibanding dengan kontrol ada perbedaan atau dengan kata lain pemberian larutan akar berdampak terhadap pertumbuhan jamur. Data hasil perhitungan LB 20\% dapat ditarik suatu keputusan bahwa data sampel pada hari ke 1 hingga hari ke 3 dengan menggunakan larutan batang konsentrasi $20 \%$ menunjukkan hipotesis awal (H0) diterima, sedangkan hipotesis alternative (H1) ditolak. Ini membuktikan bahwa untuk sampel pada hari ke 1 hingga hari ke 3 dengan menggunakan LB 20\% pertumbuhan jamur dibanding dengan KL tidak ada perbedaan atau dengan kata lain pemberian larutan akar tidak berdampak terhadap pertumbuhan jamur. Sedangkan data LB 20\% dapat ditarik suatu keputusan bahwa data sampel pada hari ke 4 hingga hari ke 14 dengan menggunakan larutan batang konsentrasi 20\% menunjukkan hipotesis awal (H0) ditolak, sedangkan hipotesis alternative (H1) diterima. Ini membuktikan bahwa untuk sampel pada hari ke 4 hingga hari ke 14 dengan menggunakan LB $20 \%$ pertumbuhan jamur dibanding dengan kontrol ada perbedaan atau dengan kata lain pemberian larutan batang berdampak terhadap pertumbuhan jamur. Data hasil perhitungan LD 30\% dapat ditarik suatu keputusan bahwa data sampel pada hari ke 1 hingga hari ke 14 dengan menggunakan LD $30 \%$ dan data sampel pada hari ke 1 hingga hari ke 14 dengan menggunakan LD $30 \%$ menunjukkan hipotesis awal (H0) ditolak, sedangkan hipotesis alternative (H1) diterima. Ini membuktikan bahwa untuk sampel pada hari ke 1 hingga hari ke 14 dengan menggunakan LD 30\% dan data sampel pada hari ke 1 hingga hari ke 14 dengan menggunakan LD $30 \%$ pertumbuhan jamur dibanding dengan kontrol ada perbedaan atau dengan kata lain pemberian larutan batang berdampak terhadap pertumbuhan jamur. Data hasil perhitungan LD dapat ditarik suatu keputusan bahwa data sampel pada hari ke 1 hingga hari ke 14 dengan menggunakan LD 20\%, 30\%, 40\% menunjukkan hipotesis awal (H0) ditolak, sedangkan hipotesis alternative
(H1) diterima. Ini membuktikan bahwa untuk sampel pada hari ke 1 hingga hari ke 14 dengan menggunakan LD 20\%, 30\%, 40\% pertumbuhan jamur dibanding dengan kontrol ada perbedaan atau dengan kata lain pemberian larutan daun berdampak terhadap pertumbuhan jamur. Hasil jenis jamur dengan menggunakan teknik PDA diperoleh bahwa jenis yang tumbuh adalah jamur merang (Gambar 4-12). Gambar 4-12 (A, C, E, G, I, K) perlakuan normal dan Gambar 4-12 (B, D, $\mathrm{F}, \mathrm{H}, \mathrm{J}, \mathrm{L}$ ) perlakuan sterilisasi.

Semua perlakuan pada penanaman benih spora jamur di jerami menggunakan media PDA (Potato Dextro Agar). C dan D merupakan hasil penanaman spora pada perlakuan pertama. Pada perlakuan E dan F mulai terlihat tumbuh jamur sedikit. Pertumbuhan jamur pada perlakuan $\mathrm{G}$ dan $\mathrm{H}$ terlihat dengan jumlah sedang. Pertumbuhan jamur pada perlakuan I dan J terlihat banyak. Pertumbuhan jamur pada perlakuan K dan L terlihat sangat banyak. Gambar M Media PDA ke-2 untuk proses pemurnian (M). Penanaman pertama untuk pemurnian yang diambil dari spora hasil perlakuan gambar $\mathrm{L}$ (N), Gambar K tidak dipilih karena banyak terkontaminasi oleh bakteri. Terlihat sedikit sekali jamur yang tumbuh (O). Pertumbuhan jamur terlihat sedang (P). Pertumbuhan jamur terlihat agak banyak (Q) dan pada erlihat pertumbuhan jamurnya sangat banyak (R). Berdasarkan hasil perhitungan hipotesis menunjukkan bahwa pertumbuhan jamur pada sampel eksperimen menggunakan LD berbeda dengan pertumbuhan jamur pada sampel KL. Ini membuktikan bahwa larutan daun sirih hutan memiliki dampak terhadap pertumbuhan jamur merang. Dampak tersebut dikarenakan adanya perubahan $\mathrm{pH}$ atau tingkat keasaaman pada media pertumbuhan jamur tersebut yang sesuai dengan kebutuhan keasaman pertumbuhan jamur merang. Pertumbuhan jamur yang maksimum berasda pada pH 5,0 sampai 10,0 (Abubakar A, et al, 2013). Hasil penelitian yang sama juga dilakukan oleh (Ichsan, C.N, et al, 2011) dengan menggunakan jamur merang dan media tanam dengan konsentrasi pupuk biogreen yang berbeda perlakuan dengan 
penelitian ini. Hasil uji hipotesis dari tiga perlakuan juga membuktikan bahwa penggunaan LD lebih baik dibanding penggunaan LA dan LB. Ini dibuktikan dengan beberapapa perhitungan uji hipotesis pada penggunaan LA dan LB masih ada yang sama dengan KL. Pertumbunhan spora pada sampel yang menggunakan LD dikarenakan daun mengandung zat nutrisi yang dibutuhkan oleh pertumbuhan jamur yang berdampak pada $\mathrm{pH}$ semakin kecil atau sedikit. Keasaman $(\mathrm{pH})$ yang kecil atau sedikit lebih baik untuk pertumbuhan jamur (Anjisha R. Maharshi and Vrinda S. Thaker, 2012). Sedangkan untuk LB dan LA kurang mengandung nutrisi yang dibutuhkan untuk pertumbuhan jamur yang dimaksud. Penggunaan LA yang paling baik yakni dengan LA 25\%, dibanding dengan LA $50 \%$ dan LA $75 \%$. Ini dibuktikan dengan beberapa perhitungan uji hipotesis pada penggunaan LA $25 \%$ memiliki nilai a symp sig 2 tailed 0,280 > dari 0,05 pada hari ke 2 . Hasil seperti ini membuktikan juga bahwa konsentrasi larutan sirih hutan memiliki pengaruh kuat terhadap pertumbuhan jamur. Pegaruh konsentrasi larutan terhadap pertumbuhan jamur didukung oleh hasil peneleitian sebelumnya yakni (Hassan. R, et al, 2015) yang menyatakan hasil penelitian diperoleh bahwa efek dari delapan asam organik (propionat, asetat, formic, laktat, tartarat, sitrat, oksalat dan malasam es) sebagai agen anti jamur pada pertumbuhan empat jamur (Aspergillus flavus, Penicillium purpurogenum, Rhizopusnigricans dan Fusarium oxysporum) pada konsentrasi tinggi delapan asam organik (10\%) memiliki efek penghambatan tertinggi terhadap pertumbuhan empat jamur, pada konsentrasi rendah delapan asam organik (5\%) terhadap pertumbuhan empat jamur.

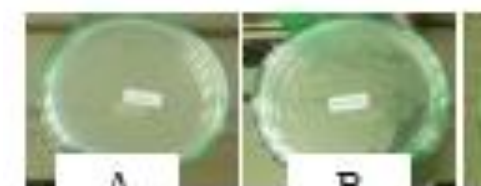

A

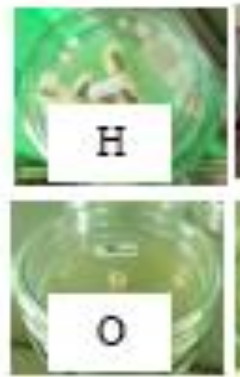

Penggunaan LB 20\% yang paling baik yakni dibanding dengan LB $30 \%$ dan LB $40 \%$. Ini dibuktikan dengan beberapa perhitungan uji hipotesis pada penggunaan LB $20 \%$ memiliki nilai a symp sig 2 tailed $0,353>$ dari 0,05 pada hari ke 5. Hasil seperti ini membuktikan juga bahwa konsentrasi larutan sirih hutan memiliki pengaruh kuat terhadap pertumbuhan jamur. Daya tahan pigmen merah Penicillium purpurogenum 1,5\% berpengaruh signifikan $(\mathrm{P}<0,05)$ terhadap pertumbuhan jamur Fusarium oxysporum dan jumlah koloni fungi Fusarium oxysporum dibandingkan daya tahan pigmen merah

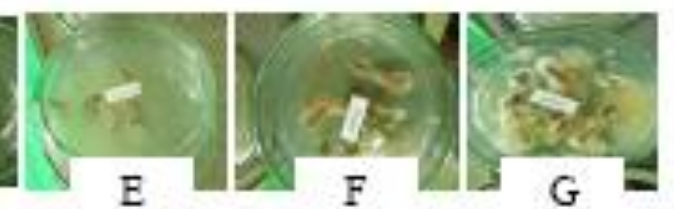

$\mathrm{D} \Delta \mathrm{E}$

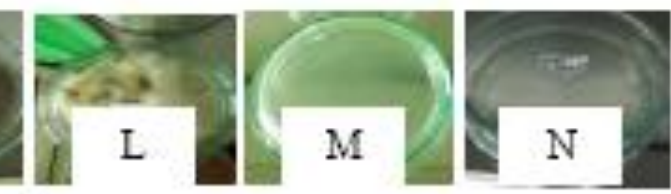

$\mathrm{R}$
Penicillium purpurogenum 0\% dan 0,5\% (Widayati. S, et al, 2017). Pertumbuhan jamur Fusarium oxysporum pada media PDA mengandung pigmen merah Penicillium purpurogenum $1,5 \%$ signifikan $(\mathrm{P}<0,05)$ lebih kecil dari pertumbuhan jamur Fusarium oxysporum pada media PDA yang mengandung pigmen merah Penicillium purpurogenum $0 \%$ dan 0,5\%. Penicillium purpurogenum dapat menghambat pertumbuhan dan jumlah koloni fungis Fusarium oxysporum.

Penggunaan LD 30\% yang paling baik dibanding dengan LD 20\% dan LD 40\%. Ini 
dibuktikan dengan beberapa perhitungan uji hipotesis pada penggunaan LD 30\% memiliki nilai a symp sig 2 tailed $0,353>$ dari 0,05 pada hari ke 5. Hasil seperti ini membuktikan juga bahwa konsentrasi larutan sisrih hutan memiliki pengaruh kuat terhadap pertumbuhan jamur. Pengaruh ekstrak jenis daun sirih terhadap jamur Candida albicans, dan ada pengaruh variasi konsentrasi terhadap pertumbuhan jamur Candida albicans. Hal ini diperlihatkan hasil bahwa jenis daun sirih dan variasi konsentrasi berpengaruh terhadap pertumbuhan jamur Candida albicans (Utami. D. E. R., et al, 2015).

Larutan yang digunakan pada penelitian ini dari akar, batang, daun Piper aduncum $L$ dapat memicu pertumbuhan jamur namun larutan yang paling efektif yakni LD $30 \%$.

\section{KESIMPULAN}

Hasil penelitian dapat disimpulkan bahwa: 1. LD sirih hutan dapat memicu pertumbuhan jamur Volvariella volvaceae $L$ Konsentrasi terbaik yakni pada konsentrasi $25 \%$ a symp sig 2 tailed $0,280>$ dari 0,05 pada hari ke 2. 2. LB sirih hutan dapat memicu pertumbuhan jamur Volvariella volvaceae $L$. Konsentrasi terbaik yakni $20 \%$ a symp sig 2 tailed 0,353 > dari 0,05 pada hari ke 5. 3. LD sirih hutan dapat memicu pertumbuhan jamur Volvariella volvaceae L. Konsentrasi terbaik yakni 30\% a symp sig 2 tailed $0,353>$ dari 0,05 pada hari ke 5. 4. LA, LB dan LD secara keseluruhan dapat memicu pertumbuhan jamur Volvarialla volvaceae $L$ dan yang terbaik adalah LD 30\% a symp sig 2 tailed 0,353 > dari 0,05 pada hari ke 5 .

\section{DAFTAR PUSTAKA}

Abubakar A, et al. (2013). Effect of $\mathrm{pH}$ on mycelial growth and sporulation of Aspergillus parasiticus. Journal of Plant Sciences $1(4)$

(doi: 10.11648/j.jps.20130104.13 ), 64-67.

Anjisha R. Maharshi and Vrinda S. Thaker. (2012). Growth and Development of Plant Pathogenic Fungi in Define Media. European Journal of Experimental Biology (ISSN: 2248 -9215), 44-54.

Aziz. S.M.A, et al. (2015). Edible
Mushrooms: A Green Biotechnology and Great Nutritional Value for Improving Human Health. International Journal of Science and Engineering , 1.

Boa, E. (2004). Wild edible fungi: a global overview of their use and importance to people. Italy: NonWood Forest Products, No. 17, FAO, Forestry Department,Rome, Italy.

Carlile. M.J and Watkinson. S.C. (1995). The Fungi. San Diego: Academic Press.

Chang. (1993). Mushroom biology: the impact on mushroom production and mushroom products. In: S.T. Chang., J.A. Bushwell and S.W. Chin (eds.). Mushroom biology and. Hongkong: The Chinese University Press.

Hassan. R, et al. (2015). Effect Of Some Organic Acids On Some Fungal Growth And Their Toxins Production. International Journal of Advances in Biology (IJAB) , Vol 2. No .1, 1-11.

Ichsan, C.N, et al. (2011). Karakteristik Pertumbuhan Dan Hasil Jamur Merang (Volvariella Volvacea L.) Pada Media Tanam Dan Konsentrasi Pupuk Biogreen Yang Berbeda. Jurnal Floratek , 1-10.

Jinus, et al. (2012). Pengaruh Zat Pengatur Tumbuh (ZPT) Root-Up dan SuperGA erhadap Pertumbuhan Akar Stek Tanaman Jabon (Anthocephalus cadamba Miq). Jurnal Sains dan Matematika , 1-6.

Martina, L. (2004). Blotong Menambah Isi Kantong. Jakarta: Intisari. Ningsih. H. U., et al. (2015). Aktivitas Larutan Piper Betle Terhadap Perkembangan Bakteri Pada Ikan Air Laut. Biolearning Journal , 04 (ISSN: 2406-8233), 1-8.

Prakash. A, Rao J. (1997). Botanical Pesticides in Agriculture. Boca Raton: CRC Press.

Pramita. I, et al. (2015). Pengaruh Kapur dan Dolomit Terhadap Pertumbuhan Miselium dan Produksi Jamur Kuping Hitam (Auricularia polythrica (Mont.) Sacc.). Online Jurnal of Natural Science , 1 .

Sasabone. A, et al. (2016). Optimasi 
Pengolahan Gula Dari Buah Tumbuhan Sirih Hutan (Piper Caducibracteum C.Dc). Biolearning Journal,

Semwal. KC, et al. (2014). Mushroom: Nature's Treasure in Ethiopia. Momona Ethiopian Journal of Science (MEJS) , 6 (ISSN: 2220-184X), 1-10.

Suganda, T. (1995). Quantification of Vascular Colonization as Means to Evaluate Resistance of Potato to verticillium albo-atrum and $V$. dahliae. PhD. Thesis. USA: available at perpustakaan Faperta Unpad.

Sumarsih, S. (2010). Untung Besar Usaha Bibit Jamur Tiram. Jakarta: Penebar Swadaya. Utami. D. E. R., et al. (2015). Pengaruh Jenis Sirih Dan Variasi Konsentrasi Ekstrak Terhadap Pertumbuhan Jamur Candida Albicans. BIOTA: Jurnal Tadris IPA Biologi FITK IAIN Mataram , 7, 143-156.

Valverde. ME, et al. (2015). Edible
Mushrooms: Improving Human Health and Promoting. International Journal of Microbiology, 1-14.

Wahidah. B.F, et al. (2015). PerbedaanPengaruh Media Tanam Serbuk GergajidanJerami Padi TerhadapPertumbuhan Jamur Tiram Putih(Pleurotus ostreatus). Biogenesis Jurnal Ilmiah Biologi , 3 (ISSN 2302-1616), 11-15.

Wetherell, D. F. (2002). Pengantar Propagasi Tanaman secara in-vitro. Wayne New Jersey: Avery Publishing Group Inc.

Wibowo, Z. (1983). Pengaruh Mg Tanah Dan Pemupukan Mg Terhadap Pertumbuhan Tanaman. Hasil Penelitian Pertanian Indonesia.

Willard, T. (2006). Reishi Mushroom: Herb of Spiritual Potency and Medical Wonder. Washington, DC: Sylvan Press.

Winarno, F. (2004). Kimia Pangan dan Gizi. Jakarta: PT. Gramedia Pustaka Utama. 